\title{
КОНДЕНСАЦІЯ В УКРАЇНСЬКІЙ ОСЕЛІ МАТЕРІАЛЬНОЇ ТА ДУХОВНОЇ КУЛЬТУРИ НАРОДУ (НА МАТЕРІАЛІ ФРАЗЕОЛОГІї)
}

\footnotetext{
Свердан Т. П. Конденсація в українській оселі матеріальної та духовної культури народу (на матеріалі фразеології).

У статті встановлено семантичний спектр фразеологізмів з концептом хата з урахуванням його лексичних і символічних значень; на основі фразеологізмів із зазна-ченим вище концептом з'ясовано важливість рідної домівки для українців; окреслено риси українського національного характеру, відбиті в аналізованому матеріалі.

Ключові слова: фразеологізм, концепт, компонент, ментальність, культура.
}

Свердан Т. П. Конденсация в украинском жилище материальной и духовной культуры народа (на материале фразеологии).

В статье установлено семантический спектр фразеологизмов с концептом хата с учетом его лексических и символических значений; на основе фразеологизмов с указанным выше концептом выяснено значение (важность) родного дома для украинцев; очерчены особенности украинского национального характера, отраженные в анализируемом материале.

Ключевые слова: фразеологизм, концепт, компонент, ментальность, культура. phraseology).

Sverdan T. P. Condensation in Ukrainian home of material and spiritual culture of people (based on

In this article semantic range of phraseology to the concept of house considering its direct and symbolic values are set. The importance of native home for the Ukrainians is found out on base of idioms above. The features of the Ukrainian national character reflected in the material are outlined.

Key words: phrases, concept, components, mentality, culture.

Фразеологічна одиниця (далі - ФО), як і слово, - одна 3 основних одиниць мови. I якщо ми прагнемо говорити про національно-культурний колорит мови (проблема, яку сьогодні активно обговорюють), то його перш за все треба шукати в лексиці та фразеології й особливо в тих їхніх сферах, які прямо чи опосередковано пов'язані з соціально-етнічними та національно-культурними особливостями побуту носіїв мови. І. Франко небезпідставно характеризував, зокрема, прислів'я, як важливе пізнавальне джерело, «що вводить нас у дух язика, в психологію народу, показує in flagranti процес творення місцевої та історичної традиції, вірувань, поведінок...» [14, с. 44]. ФО вже навіть 3 формального боку може сигналізувати про багато культурно-історичних та соціоетнічних характеристик. Проте національно-культурна своєрідність фразеологізмів, яка виявляється у плані вираження, складає лише частину такого типу інформації, причому не найголовнішої. Основне навантаження тут виконує

(С Т. П. Свердан, 2011. 
фразеологічне значення, на рівні якого розкриває свою національнокультурну специфіку змістовий аспект фразеологізму й особливо у смислових розходженнях переносних значень відповідних багатозначних ФО у двох чи кількох мовах.

Студіювання мовознавцями фразеологізмів у руслі культурології зумовлене поглядом на ФО як на мовний знак, що: 1) передає інформацію; 2) зберігає і відтворює культурні настанови народу, знак, уся семантика якого наскрізь пронизана культурою [8, с. 327]. Адже семантику ФО можна показати як інформаційний текст, різноманітні значення якого проходять через «фільтр» ментальності мовної особистості й трактовані у просторі соціального та культурного знання, активізованого мовцем у момент спілкування. Тобто світогляд кожного народу, специфіка його етномислення досить виразно виявлена у фразеологічній системі мови, а отже, ФО української мови - важливе пізнавальне джерело психології українського народу, його вірувань, досвіду та історико-культурних традицій. Нас зацікавили фразеологічні одиниці 3 концептом хата, оскільки вони досить широко й точно передають світогляд та риси характеру українців. Адже для українця хата була i $\epsilon$ символом незалежності, затишку, добробуту, достатку, господарності, працелюбності, оберегу i, зрештою, останнього подиху на межі ,цього i того світу». Традиційна українська хата - воістину колиска нашого народу. У ній жили, сподіваючись на кращу долю, цілі покоління.

Актуальність нашої студії зумовлена активним розвитком такого напряму вивчення фразеології, який скерував увагу багатьох мовознавців (наприклад, Л. Мельник (дисертація на тему «Культурно-національна конотація українських фразеологізмів», захищена 2001 р. у Донецьку), Л. Даниленко (дисертація на тему «Національно-культурні особливості семантики чеських фразеологізмів», захищена 1997 р. в Києві), Г. Онкович [5], Л. Савченко [7], Д. Ужченка [11] та ін.) до компонентної організації ФО й активізував дослідження взаємозв'язку раціонального та емоційнообразного значення фразеологізмів, пов'язаного з фоновим контекстом окремих компонентів-концептів. Мета статті - установити семантичний спектр фразеологізмів 3 концептом хата з урахуванням його прямих $\mathrm{i}$ символічних значень; на основі зібраних фразеологізмів із зазначеним вище концептом з'ясувати значення (важливість) хати (рідної домівки) для українців; окреслити риси українського національного характеру, відбиті в аналізованому матеріалі.

Семантичний спектр українських ФО $з$ концептом хата значно ширший, ніж їх символічний простір, що зумовлено низкою причин, зокрема переосмисленням, метафоризацією первісних значень, розвитком додаткових відтінків значень i под. Загалом концепт розуміємо як локалізоване ментальне утворення, що відбиває об'єктивний світ. Власне концепт хата розуміємо як психоментальну особливість українського 
народу, що відбита у свідомості людей і закладена на підсвідомому рівні мислення людини. В українській мові цей концепт виражений лексикосемантичною групою хата, що складається зі слів хата, diм, двір, господарство, хазяйство, комора, стодола, хлів, клуня, стайня, які становлять синонімічний ряд із домінантою хата (далі спробуємо з'ясувати значення фразеологізмів, до складу яких входять зазначені вище слова-компоненти). Саме це слово, незважаючи на синонімічну конкуренцію зі словом дім у його прямому значенні, ми, вслід за О.Сфименко, визнаємо домінантним як найменш ускладнене додатковими семантичними компонентами, таке, що безпосередньо виражає концепт [1, с. 7].

Одинадцятитомний «Словник української мови» подає такі значення слова хата: «Хата, и, ж. 1. Сільський одноповерховий житловий будинок // Домівка, господа // Тимчасове пристановище для кого-небудь. 2. Внутрішнє житлове приміщення такого будинку // Кімната. Велика хата - простора, світла кімната для прийому гостей; світлиця. Мала хата хатина. 3. Родина, люди, які живуть, перебувають в одному такому приміщенні. 4. розм. Квартира. 5. Уживається у складі назв деяких сільських установ. Хата-лабораторія. Хата-читальня [8, XI, с. 30]. Зауважимо, що значення 3 відбиває сприймання українцями хати не лише, як певної будівлі, а і як сім’ї, найдорожчих людей (хата = родина).

Аналіз фактичного матеріалу показує, що компонент хата у значенні 1 найчастіше входить до складу ФО на позначення незалежнності. Адже 3 давніх-давен власна хата була (і є!) мрією кожної людини: чужа хата не гріє [6, с. 137]; чужа хата - велика досада [12, с. 187]; у своїи хаті кождий пан [6, с. 136] - тут цікавими є поєднання чужа - не гріє, досада, а своя $n a н$. Така мрія яскраво зафіксована в єдиному 3 нашої картотеки фразеологізмі з компонентом будинок: і тісний будинок, але коли власний найкращиий [2, с. 336].

Наявність власної оселі виводила людину на певну сходинку громадського визнання, означала, що вона працьовита, клопочеться про прихисток і достаток для своєї сім’ї. Хата мусить бути лише своя, про що досить виразно свідчать такі фразеологізми: збудуй (постав) хату 3 лободи, а до чужої не веди [12, с. 171]; будуй хату хоть з лободи, а в комірне не йди [6, с. 133]; збудуй хатку з маковини та для любої дівчини [6, с. 133] - так звертається дівчина до парубка, який хоче 3 нею побратися, оскільки нічого гіршого немає, ніж жити в чужій хаті, і лише у свойй хатісвоя правда, $i$ сила, $i$ воля [12, с. 186]. Останній вислів належить Т. Шевченку, але він настільки тісно переплівся з народною психологією, що став сприйматися як зразок усної народної творчості. Зауважуємо й інші варіанти: чия хата, того й правда [12, с. 186]; своя хата й своя воля [12, с. 187]; своя хата - своя правда, своя стріха - своя втіха [12, с. 186]; своя хата (стріха) - своя правда (втіха), а комірщчина гірка [6, с. 136]. 
Оскільки всім відомо, що в одній хаті дві сковорідки не миряться [2, с. 211], дуже часто свекрухи казали своїм невісткам: мусии привикати, бо не маєш своєї хати [6, с. 136]. А невістки у свою чергу відповідали: не дай, Боже, в чужій хаті жити, в чужій печі топити [6, с. 137]. Можливо, тому чужу хату порівнюють зі свекрухою: хата чужая - як свекруха [лихая] [12, с. 187].

Фразеологізми $і$ собаці своєї хати хочеться [6, с. 136], бодай $i$ пес (собака) свою хату мав (мала) [12, с. 187] додаткове підтвердження того, що не тільки людині, а й тваринам потрібне житло. Можливо, тому черепахи і равлики носять свою хатку на собі й цим ніби хочуть показати людям, що ніколи не потрібно залишати рідну домівку, бо у свої хаті легше умирати [6, с. 136]. Своєрідним застереженням-порадою звучить фразеологічна одиниця не надійся на чужу хату, бо під тином доведеться умирати [6, с. 137], а тому ліпша своя найгірша хата, ніж чужа найпрекрасніша палата.

Загалом аналіз ФО аналізованої групи показує, що у їх складі: 1) досить поширеною є частка не у поєднанні з дієсловами (не надійся, не миряться, не дай, не маєи, не повинна нічого знати, не йди, не веди, не гріє тощо), займенниками (не своя, не моя), прислівниками (не вільно), іменниками (не ворог), яка підкреслює застережний характер цих фразеологізмів; 2) послідовно використовувано займенник своя і прикметник чужа (антоніми), які акцентують увагу на власній приналежності чи відсутності такої; 3) частими є порівняння (своя хата, як покришка: коли прийдеш, прийме [12, с. 201]).

Наш фактичний матеріал фіксує також значну кількість ФО 3 компонентом хата, що позначають злидні. Попри те, що кожна людина, незалежно від соціального статусу, мріє про власну хату, трапляється так, що, маючи оселю, люди не дбають про неї: дожилися до того, щзо хоч серед хати орати [4, с. 45] - пустка, злиденне перебування; не має ані хвоста коло хати [6, с. 177] - відсутність худоби (хвоста) є ознакою надзвичайної бідності. Бували (i $\epsilon$ !) випадки, коли через бажання похизуватися будували надто великі хати, витрачаючи гроші до останньої копійки, так, що і на їжу не вистачало, порівн.: хата велика, $\epsilon$ де cicmu, ma нічого їсти [6, с. 135]. Про такі великі хати іноді казали: так моя добра хата, як твоя кімната [12, с. 187]. Коли хата була дуже маленькою, а людей у ній жило багато, то казали: тісняться, наче хата у печі [2, с. 470] тут зафіксовано в мові пам’ять про перші житла - печери-печі.

3-поміж ФО на позначення злиднів поширеними є вислови-поради: угли обрубуй, а хату отоплюй [12, с. 201] - нашаровується сема «затишок»; треба хати холодити (гонить вітер по хаті - от, як панночки ходять юрбою) [12, с. 201] - зауважуємо іронію. Про таку хату, у якій нічим було топити, казали так: така хата тепла, щзо стойи дрижачи [12, с. 275]; на ката й хата, як топить нічим [6, с. 134] - гірка іронія; 
холодно в хаті, щзо й собаку не вдержиш [6, с. 135]. В одній з останніх збірок прислів ’їв та приказок знаходимо повніший варіант цієї ФО: так холодно в хаті, щзо пса на ланц̧югу не вдержии [2, с. 65] - компонент на ланц̧югу підсилює загальне значення виразу.

Іноді через злидні між членами родини виникають сімейні суперечки: як у млині не мелеться, то в хаті колотиться [2, с. 237]; як на току молотиться, то в хаті не колотиться, а як на току не молотять, то в хаті колотять [2, с. 179] - у цих фразеологізмах слово-компонент хата виступає у значенні 3 (родина), фіксованому «Словником української мови», а на основне значення ФО «злидні» нашаровується додаткове «суперечка», яке в сучасному мовленні активно витісняє перше.

Вipa в те, що доля, з народження погана, такою буде до кінця, тобто фатальний настрій панує в такому фразеологізмі: не мав пес хати, та й не буде мати [6, с. 133] та його варіанті не було в собаки хати $i$ не буде [2, с. 659]. Отже, тут також зауважуємо накладання додаткового значення «неминучість долі» на основне - «злидні».

Коли людині було важко матеріально, вона лишала свою рідну домівку і їхала на заробітки: нестатки гонять з хатки [6, с. 134]. Подібну ситуацію, на жаль, зауважуємо сьогодні. Іноді в бідній пустій хаті і сон був нестерпним: в порожній хаті сумно й спати [12, с. 279]. Можливо, тому, використовуючи дієслова-антоніми, казали: пусткою хата смердить [6, с.135] або пахне пусткою в хаті [12, с. 201]. У вказаних ФО пустка (порожнеча) є не лише буквальною, а й позначає відсутність родини, сім’і, тобто, компонент хата використано зі значенням 3.

3-поміж українських фразеологізмів, що позначають злидні, трапляються вирази, до складу яких входить два або три компоненти слова лексико-семантичної групи хата, приміром: y cmaйнi $\epsilon x в i c m$, але в xаті - постійний піст [2, с. 668]; в коморі порожньо, в стодолі пусто, а xаті - лише одне сміття [2, с. 650]; в коморі пусто, в стодолі порожньо, а в хаті лии одна верета [6, с. 143]. Таке нанизування компонентів однієї лексико-семантичної групи, доповнене синонімами пусто й порожньо і числівником одне (одна), підсилює, увиразнює значення ФО - «злидні».

Цікаво, що у складі фразеологізмів аналізованої групи зауважуємо компоненти iз суфіксами зменшеності-пестливості (демінутивними суфіксами), наприклад: хатка на курячій лапиі (ніжчі) [10, с. 241]; у нас вітер хату мете, сонечко хліб пече, вода сама ллється, все гаразд ведеться [6, с. 135], які показують по-філософському спокійно-іронічне ставлення українців до власної бідності. Фразеологічна одиниця хатка на xamu̧i [10, 2, с. 241], на нашу думку, має подвійне пояснення: по-перше, можливо, так казали, коли відстань між хатами у селі була дуже маленькою (порівн.: на світі скільки лат, скільки на селі хат [4, с. 52]), а в місті будинки, ніби об'єднані між собою, створювали враження, що одна вулиця - це один будинок. По-друге, раніше надмогильні хрести робили 3 
дерева і через певний час вони ставали гнилими і падали. Люди забували про існування могили, на якій не стало хреста, і ховали на цьому ж місці іншого небіжчика. Оскільки могила - «наша друга хата», то описана ситуація могла спричинити виникнення ФО хатка на хатці.

Для підкреслення «злиденного значення» деяких фразеологізмів до ïx складу входять компоненти-назви тварин, птахів чи комах, що мешкають поблизу або безпосередньо у людських оселях, зокрема собака (nес), миша, муха, горобецьь, віл. Наприклад: хата багата, а нічого й собащзі дати [6, с. 135] - означення багата вжито тут у переносному іронічному значенні; мимі, й ті втікають з його хати [2, с. 657]; порожньої хати $i$ муха не держиться [6, с. 135]; де то сі бідні воробиі діють, як хата згорить [6, с. 217]; без вола хата гола [4, с. 48] - основним багатством, крім хати, є худоба.

Безперечно, кожна людина хоче жити в достатку: добре лежать на печі, як єсть у хаті калачі [4, с. 60], хоча зрідка українці вміли задовольнятися й тим, що мали: коли є горіх $і$ каnуста, то хата не пуста [2, с. 93]; чим хата багата, тим і рада [12, с. 232] - так ще кажуть, коли припрошують до частування гостей. Про прагнення достатку свідчать і такі фразеологізми, як: повна хата $[13,2$, с. 921]; побажання дай, боже, одежу шиту, а хату криту [6, с. 133]; купуй хату криту, а свиту шиту [6, с. 134]; найліпша хата крита, а сукмана шита [6, с. 133] - ці ФО містять і сему 'господарність'.

Фразеологізми зі значенням господарність, що містять компонент хата, фіксуємо, приміром такі: хату руки держать [12, с. 275] - соматизм руки є символом працьовитості: працььовиті руки, роботящі руки, зроблені руки, золоті руки, умілі руки і под.; хату зробити - не стільчик збити [2, с.111] - нашарування семи 'уміння'; хто робить багато, в того добра повна хата [2, с. 177] та ін. Бачимо, що для того, щоб збудувати хату й утримувати ¥іi в належному, треба багато працювати i докладати якнайбільше зусиль. Недарма кажуть: коли хата без замка, то й свиня по ній ходить [2, с. 94], а хто хоч раз обійшов навколо хати, розумніший від того, хто мудрує на печі [2, с. 356].

Як усім відомо, раніше піч була обов'язковим елементом хати центром і функціонального, і оберегового, і естетичного вираження: не в тім річ, щзо в хаті піч, а біда, як нема [12, с. 139]; не чудна річ, щзо в хаті піч, а чудно було б, коли б ї̈ не було [6, с. 141]. Найвищі цінності інтер'єру української хати - піч з вогнем і стіл із хлібом (їжею): не хвалися піччю в нетопленій хаті [6, с. 141]; не в тім річ, щзо в хаті піч, а в тім діло, щзоб у nечi кипіло [6, с. 141]. Ці блага (піч з вогнем і стіл з хлібом) можна звести «донизу» - до ситості й тепла (розслаблення й відпочинку), тобто, до енергетичної поживи, а можна й гідніше піднести «угору» - до символів родинного вогнища-осердя, запоруки сили-родючості роду. Без перебільшення можна стверджувати, що для старих людей хата й піч уособлювали в собі увесь світ [3, с. 154].

$$
-415-
$$

( Т. П. Свердан, 2011. 
Для українців хата була найважливішим компонентом культури в широкому розумінні цього поняття: і елементом матеріальної та духовної культури, і системою світоглядних уявлень, чільне місце у якій посідали оберегові функції. Хата захищала людей не лише від несприятливих природних умов, а й від ворожих темних сил. Хата - схованка добра, добробуту, заможності, щастя. Зазвичай берегинею, охоронницею домашнього вогнища вважали жінку: господиня три вугли в хаті тримає, a господар лиш один [6, с. 130]; за господинев у хаті всі кут плачуть [6, с.129]; без хазяйки хата плаче [6, с. 129]; без господині хаті - що день без сония [6, с. 129], хоча і без хазяӥна хата сиротина [6, с. 127]; без когута хата глуха [2, с. 363]; чоловік хату тримає, а жінка скрашає [2, с. 114]. Здебільшого про двір, худобу, поле дбав господар, а про хату господиня, тому казали: без хазяйки хата не метена [6, с. 129]; без господині хата пустков смердить [6, с. 129], а тому хати і жінку все треба покривати [12, с. 173]. У цих ФО на основне значення «господарність» нашаровується додаткова сема 'важливість господині/господаря', увиразнена компонентами господиня, хазяйка, жінка, господар. Дуже часто господарі ділилися досвідом, радилися щодо ведення господарства: хата на піску довго не устоїть [6, с. 134] або інший варіант - не будуй хату з піску [6, с.134]; хто не ризикує, той хати не збудує [6, с. 135] - має значення «готовність ризикнути»; під дощ хати не криють, а коли ясно, і сама не тече [6, с. 133] або в дощ хату не покривають, а в погоду і сама не тече [6, с. 133].

У фразеологізмах зі значенням «господарність», як і у виразах на позначення незалежності, зауважуємо часте використання заперечної частки не у поєднанні з різними частинами мови, а саме: дієсловами (не хвалися, не покривають, не криють, не будуй, не зробиш, не устоїть), у т.ч. дієприкметниками (не метена), прикметниками (не чудна). Більшість ФО цієї групи, як зрештою і інших українських фразеологізмів, досить вдало побудовані, а їхні компоненти римуються: без лопати не можна 3 хати [2, с. 241]; кожух має свій дух, а вата питає, де хата [2, с. 338].

Тісно переплітаються з ФО попередньої групи фразеологізми на позначення затишку, зокрема: зимою і собака хату ставить [6, с. 134] або інший варіант - $i$ собака зимою про хату думає [там само]. Натомість літом старещь каже: «На ката хата, нам і на дворі тепло!» [12, с. 12] - містить семи «безгосподарність», «байдужість». Гарні господарі дбають про затишок, бо в затишній хаті приємніше жити самим і запрошувати гостей: $y$ чистій хаті - свіжіше, у чистому посуді - смачніше [2, с. 353]; хата не льодовня, не годиться снігу наносить [6, с. 135]; люди добрі, тепла хата, $\epsilon$ щзо їсти, є де спати - хоч зимуйте [6, с. 134]. Зі спокон віків українців вважали працьовитими людьми, які не любили байдикувати, а працювали 3 ранку до ночі, зокрема, для того, щоб було у хаті, як у дзеркалі [6, с. 134], щоб з насолодою чути: яка хатка, так й паніматка [6, с. 136] тощо. 
Попри це траплялися і ліниві люди, над яким завжди сміялися, засуджували: лінивий у свойй хаті змокне [4, с. 175]; кепський то господар, що у свойй хаті змокне [6, с. 128]; поганий господар і в свойй хаті змокне [6, с. 128]; осталася одна в хаті, не дасть ради кошеняті [6, с. 130]; в хаті наче гуси ночували [6, с. 133]. У ФО з компонентом хата зауважено, що лінь і безгосподарність зазвичай панувала там, де господарі не дбали про власний добробут: назбиралося сміття в хаті - аж двері не зачиняються [2, с. 624] - цікаво, що на сучасному етапі цей вираз може мати і переносне значення «сімейні чвари, образи», створене символічним значенням компонента сміття; однаково, щ⿻о муляра в хату, щуо свиню в город [2, с.224] - ФО містить додаткові семи «невміння», «недбалість»; кіm 3 хати (комори) - миші на стіл (танцуюють) [6, с.184]; без роботи - ані хліба, ані хати, ніде і води взяти [2, с. 241].

Лінь і невміння ужсиватися призводили до того, що життя в хаті ставало таким нестерпним, що хоч з хати тікай $[13,2$, с. 921] або хоч утікай з хати [8, XI, с. 30], оскільки, де багацько господинь, то ту хату хоч покинь [6, с. 130]; де дві господині, там хата не метена [6, с. 130]; дві господині в хаті не дадуть ради кошеняті [6, с. 130]; де дві господині в хаті, там каша несолена і хата неметена [6, с. 130].

Окрім описаних груп, фіксуємо низку фразеологізмів із компонентом хата, які мають найрізноманітніші значення. Так, наприклад, у фразеологізмі пізно колодязь копати, як хата горить [6, с. 147] сема «безгосподарність»є складником основного значення невчасність. Коли людина не дотримувалася послідовності у будівництві, про неї казали так: на чорта ворота, як нема ні хати, ні плота [6, с. 146]. На сучасному етапі функціонування вказана ФО має значення непослідовності в будь-якій справі. Коли мають на меті обдурити когось, то кажуть: niдвести nid дурного хату [13, 2, с. 921], а коли роблять усе лише з вигодою для себе, то приповідають: помагай сусідові гасити від пожежі хату, бо й твоя недалеко [2, с. 506]. Значення висловів аж хата трясеться [13, 2, с. 921; 8, XI, с. 30], на всю (иілу) хату [13, 2, с. 921; 8, ХІ, с. 30] «Словник української мови» тлумачить так: а) дужке голосно; гучно; б) дужне сильно [8, XI, с. 30]. ФО не могти хати перейти має значення «бути дуже хворим» [13, 2, с. 921], і ця неможливість переходу рідної хати є однією 3 найбільших бід людини. Фразеологізми держатися (триматися) хати [13, 2, с. 931], сидіти в хаті [8, XI, с. 30] має значе-ння "бути вдома» [8, XI, с. 30], а ФО не держатися хати, відбиватися від хати [8, XI, с. 30] - «часто не бувати вдома» [8, XI, с. 30]. ФО повертатися до хати означає «повертатися до рідного краю» [8, XI, с. 30], тобто тут збережене символічне значення хати як родового коріння, ба́тьківщини і батьківщ⿻йни.

Усі ці та інші фразеологізми так чи інакше пов'язані із символічними значеннями концепту хата і яскраво доводять, що хата надає людині не 
тільки притулок від непогоди, але й створює їй умови для повсякденного існування, у яких відновлюються сили, визріває натхнення. Загалом хата для українця $є$ основою і сенсом упродовж усього існування на землі. Порівняно $з$ нею усе маліє (навіщзо дукати, коли нема хати? [2, с. 552]; аби хата, буде досвітчана мати [6, с. 133]), бо лише тут формуються родинні стосунки, створюється своєрідна психологічна атмосфера, свій мікроклімат, у якому людина працює, відпочиває, харчується, осмислює своє буття і взаємини з довкіллям.

Окрім фразеологізмів 3 компонентом хата, українська мова знає також ФО з компонентом $\partial і м$, значення якого «Словник української мови» подає так: Дім, дому, ч. 1. Будівля, призначена для житла або розміщення різних установ; будинок. 2. Приміщення, в якому живуть люди; житло. 3 дому: а) зі свого житла; б) з рідних місць. 3. Приміщення, люди, що в ньому живуть, та їх господарство // Про сім'ю або людей, що живуть в одному приміщенні. 4. рідко. Монархи одного роду, що послідовно замінювали один одного [8, II, с. 306]. Зауважимо, що значення 3 слова дім збігається зі значенням 3 слова хата (див. вище), у якому збережено символіку роду. 3 батьківщиною пов'язане і значення 2 б). До складу ФО компонент дім входить зі значеннями 2 і 3.

Аналіз ФО з компонентом дiм засвідчив, що, як і у фразеологізмів 3 компонентом хата, найпоширенішим їх значенням $\epsilon$ значення незаленності: добре тому, хто в своєму дому [4, с. 81], бо вдома і солома їома [4, с. 82], а на чужому коні не наӥздишся, а в чиємусь домі не погосподарюєи [2, с. 497]; свій дім не чужий: із нього не підеш [6, с. 138]накладається сема «постійність, стабільність».

Під час або після гостини кажуть: в гостях добре, а дома лучче [12, с.186]; лучче дома, ніж на празнику [6, с. 138]; всюди гаразд, а дома найліпше [12, с. 187]; кожна сторона гарна, але вдома найкраще [2, с.337]; краще мамалига вдома, ніж плов на чужині [2, с. 339]. Коли ж приймають гостей, для того, аби вони почувалися добре, комфортно, кажуть: будьте як дома $[10,1$, с. 73] - ця ФО позначає вищу міру гостинності, властивої українцям.

Низка фразеологізмів мають значення господарність: без догляду дім - сарай [2, с. 81]; порядком дім стоїьь, недбалістю і хлів розвалиться [2, с. 104]. Але дім - це не лише будівля, не лише чотири стіни і стріха зверху, а в першу чергу - це люди, які живуть в ньому (див. вище значення 3), тому ворота тримаються на стовпах, а дім - на подружжі [2, с. 84]; хазяйкою дім стоїть [6, с. 129]; господиня в дому - покрова всьому [12, с.197]; хазяйка в дому - покрова всьому [6, с.129]; дім без господаря плаче [6, с. 127]; де (як) кота нема вдома, там (то) миші брикають (гуляють) [6, с. 184]; не дім господаря красить, а господар дім [6, с. 129].

3-поміж аналізованих ФО зауважуємо деякі зі значенням оберегу, захисту що перегукується із давнім призначенням хати-дому: мій дім - 
моя фортеия: свій дім - не ворог, коли прийдеш, то прийме [12, с. 186]; вдома і стіни помагають (гріють) [12, с. 187]; затишку: коли б [о]це дома на печі та ще й у просі [6, с. 140]; внутрішнього спокою: за морем [, може, ü] тепліме, зате (та) вдома веселіме (миліше) [6, с. 138]; взаєморозуміння: згода дім будує, а незгода руйнує [6, с. 138]; повної свободи: коти з дому - миші в танецьь [6, с. 184]; взаємозалежсності: як дома пироги, той в гостях пироги [12, с. 233]; як не мають домів - щоб $i$ щзастя не мали [12, с. 21]; який господар, такий і дім [6, с. 129]; хто кочує, той дома не ночує [2, с.354]; хто в дорозі, у того й доля, а хто вдома сидить, у того вона спить [2, с. 354] тощо.

У низці фразеологізмів відбиті негативні реалії життя, зокрема: жнадібність, скупість: грубе поліно вогонь гасить, скупа хазяйка дім соромить [2, с. 86]; важко набереш - додому не донесеш [2, с. 483]; дворуиність, вигода: бути $i$ вдома й замужем [13, с. 72]; вибагливість: того мені бажається, чого дома не мається [4, с. 140]; марнотратство: погана дружина винесе фартухом з дому більше, ніж чоловік сімома кіньли завезе [2, с. 103] і под. Значення безгосподарності і лінощів мають такі ФО: наріжний камінь криво покладеш - увесь дім ненадійний [2, с.497]; якби хотів Хома, то робив би й дома [2, с. 543]; чоловік по весіллях скаче, а дома жінка з голоду плаче [2, с. 640] - тут виразно виділяються семи 'марнотратство' і 'гультяйство'; хоч mu йди в ліс по дрова, а я буду дома, хоч я буду дома, а ти йди в ліс по дрова [4, с. 72] зауважуємо додаткову сему 'хитрість'; горе тому, хто сидить даремно в дому [6, с.138]; горе тому, в кого нема порядку в дому [6, с. 138] - цікаво, що тут зауважуємо іменник горе, який підкреслює особливе ставлення українців до лінивих людей: лінь - це погана якість людини, яка ні до чого доброго не приводить і навіть є причиною горя та основою бідності. Деякі ФО з компонентом дім позначають злидні, бідність: $i$ mu mym, $і$ я туm, a дома собаки миски б’ють [2, с. 336]; не первина - ні з чим додому [2, с. 223]; ні з чим у млин, так порожняком додому [4, с. 55].

Як бачимо, фразеологізми 3 компонентом дім мають досить розгалужений спектр значень на позначення різноманітних реалій людського життя і побуту.

До лексико-семантичної групи концепту хата входить і слово двір, яке, за «Словником української мови» має такі значення: Двір дво́ру, ч. 1. Господарська ділянка, на якій розміщені садибні будівлі, та місце біля них (часто відгороджене). 2. Сільська хата з усім господарством при ній // Одиниця обліку господарств у селі... 3. іст. Присадибне господарство землевласника - поміщика, монастиря і т. ін., маєток // перен. Поміщик і його оточення. 4. іст. Виробнича одиниця - завод, майстерня. $\Delta$ Монетний двір - підприємство, що карбує монети та виготовляє інші державні знаки. 5. Приміщення для тварин, реманенту, різних матеріалів і т. ін. Двір 2 , дво́ру, ч. У монархічних країнах - монарх і його оточення 
[8, II, c. 218]. Як бачимо, двір безпосередньо пов'язаний з хатою (значення $1,2)$ i у значеннях 3 (перен.) та двір ${ }^{2}$ частково зберігає символічне значення, пов'язане з людьми (родина).

До складу українських ФО входить компонент двір ${ }^{l}$ зі значеннями 1 , 2,5 . Фразеологізми з аналізованим компонентом і синонімічним до нього подвір'я найчастіше мають значення злиднів, наприклад: $i$ хвоста нема в дворі [6, с. 132]; ні шерстинки у дворі: голий як бубон [6, с. 132]; коло двора нечиста ма (чортма) ци кола [12, с. 32] тощо; незалежності (загальновідомо про етнічні риси незалежності та індивідуальності українців у забудові двору): у всякому подвір'ї є своє повір'я [6, с. 132] зауважуємо сему «індивідуальність»; у своєму двору $i$ в собаки хвіст трубою [6, с. 132]; на своїм подвір'ї і собака пан [6, с. 132], а на чужім подвір'ю і тріски б'ють [12, с. 187] і господарності, працьовитості: без праиі нема ні кола, ні двора, ні торби, ні реміния [2, с. 154]; всякий двір хазяйським оком держиться [6, с. 127] - додаткова сема «пильність»; тазду можна впізнати по двору, а таздиню - по коморі [6, с. 127]; роби надворі буде $i(\breve{u})$ в (у) коморi [6, с. 132] - зауважуємо зіставлення двір - комора, яке пов'язане з розподілом господарських обов'язків чоловіка та жінки i залежністю між роботою біля худоби, на землі та наповненістю комори продуктами харчування. Окрім того, фіксуємо низку ФО з компонентом двір, що мають такі значення: безгосподарність, лінощі: у лінивого що на дворi, те ц̌ y коморі [2, с. 636] - аналізоване вище зіставлення; взаємозалежність: статок у дворі, а нестаток - на базарі [2, с. 269] містить додаткову сему «марнотратство»; вnерmicmb: хоч піду до їх, та не піду в двір [4, с. 170] - так жартівливо кажуть про прохану людину.

Отже, зауважуємо, що ФО з компонентом двір кількісно менше, ніж фразеологізмів з компонентами хата, дім і спектр їх значень дещо вужчий.

Значення слова господарство, яке теж входить до лексикосемантичної групи концепту хата, «Словник української мови» подає так: Господарство, а, с. 1. Сукупність виробничих відносин того чи іншого суспільного укладу; спосіб виробництва. 2. Все, що складає виробництво, служить виробництву; економіка. 3. Галузь якого-небудь виду виробництва; виробнича одиниця. 4. Обладнання, інвентар, будівлі і т. ін. якого-небудь виробництва або виробничої одиниці // розм. Сукупність предметів, речей, належних кому-небудь. 5. Сільськогосподарська виробнича одиниця із знаряддями і засобами виробництва, з ділянкою землі, худобою і т. ін. 6. Виробнича, фінансова і т. ін. сторона побуту [113, II, с. 141]. Слово господарство зі значеннями 5 і 4 (розм.) входить до складу небагатьох українських ФО, які мають такі значення: злидні: на моӥм господарстві ніщо не проросте [6, с. 131]; все своє господарство забрав з собою [6, с. 131] - так кажуть про дуже бідну людину, яка за все життя не надбала жодного добра; госnодарність: привикай до господарства змолоду, то не будеш знати на старість голоду [12, с. 197] - 
так часто повчають батьки своїх дітей, щоб ті у майбутньому стали добрими господарями.

Подібним за значенням до слова господарство є слово хазяйство, яке «Словник української мови» тлумачить так: Хазяйство, а, с. 1. Виробнича, передусім сільськогосподарська, одиниця із засобами виробництва (землею, худобою і т. ін.); господарство (у 5 значенні) // Дім разом 3 предметами хатнього вжитку, надвірними будівлями, садибою. 2. Майно якого-небудь виробництва або виробничої одиниці (земельні угіддя, господарські будівлі, інвентар, продукти харчування і т. ін.) // Сукупність предметів, речей індивідуального вжитку. 3. Господарська діяльність; господарювання. 4. розм. Збірн. до хазяїн [8, XI, с. 10].

Фразеологізмів з компонентом хазяйство (у значеннях 1 і 2 //) також є небагато і мають вони такі значення: господарність і заощадливість: 8 хазяйстві все знадобиться [6, с. 131]; застереженння від безгосподарності $\boldsymbol{i}$ гультяйства: не в дорогу вдавайся, а в хазяйстві кохайся [12, с.197]; підеш дідовим шляхом - піде хазяйство прахом [6, с. 131]; злидні: хазяйство мовчить та шийку тониить [6, с. 131]; відповідальність: бути (залишатися, зоставатися $i$ под.) на хазяйстві [8, XI, с. 10] - залишатися порядкувати у дворі чи хаті; nidcmynнicmb: зводити з хазяйства [8, XI, с.10] - підступно заволодіти чиїмось майном.

Значно більше ФО фіксуємо зі словом комора, значення якого «Словник української мови» подає так: Комора, и, ж. 1. Окрема будівля для зберігання зерна тощо. 2. Приміщення в житловому будинку, де тримають продукти харчування, хатні речі тощо. 3. рідко. Те саме, що склад ${ }^{1}$. *У порівн. У деяких тварин шлунок, немов комора [8, IV, с. 248].

Комора пов'язана як 3 господарським комплексом, так i безпосередньо 3 хатою. Компонент комора (у значеннях 1 і 2), як і компонент хата, входить до складу ФО, що переважно мають значення взаємозалежнності, господарності й статків: більше хліба в полі-більше і в коморі [2, с. 81]; клади гній густо - в коморі не буде пусто [2, с.93]; хто добре оре, той має зерно в коморі [2, с. 233] - зауважимо, що у всіх вказаних випадках поряд 3 компонентом комора послідовно використовується компонент в (y), який свідчить, що йдеться не про зовнішній вигляд комори, а про внутрішнє наповнення, тобто, про статки. На позначення злиднів і злигоднів фіксуємо такі ФО: у мене дві комори: водній пусто, а в другій горе [6, с. 143]; в мене три повні комори: в одній вітер, в другій збитий горнецьь на мак, а третя стоїть так [6, с. 143]. Окрім того, зауважуємо фразеологізми з компонентом комора, що мають такі значення: пустопорожнні обіцянки, невідповідність слова й діла: багато на умі, та мало в коморі [2, с. 507]; не той урожай, щзо на полі, а той, щзо в коморі [4, с. 31]; не вір гречизі на цзвіту, а вір у коморі [2, с.135]; безпринципність, безхарактерність людини: ні те, щуо в полі, ні те, щуо в коморі [2, с. 224]; залежсність від обставин: не замісиш густо, коли в 
коморі пусто [4, с. 85]; поміркованість, виваженість дій: у порожню комору вовк не лізе [6, с. 143]; на пусту комору замка не вімають [6, с.143]; порядок, лад: у людській коморі не годиться людей тримати [2, с.668]; достаток: до готової комори добре дрова рубати [2, с. 214]; свавілля: цар у державі, як кіт у коморі: кого піймав, того й з ’̈в [4, с. 44].

Одним із об’єктів господарської садиби $є$ стодола. «Словник української мови» тлумачить слово стодола так: Стодола, и, ж. Будівля для зберігання снопів, сіна, полови тощо, а також для молотьби, віяння і т. ін.; клуня [8, IX, с. 724]. Наша картотека містить лише 5 ФО з компонентом стодола, які мають пряме значення злидні, підкреслене прикметником пуста (порожня), і такі фразеологічні значення, як: взаємозалежність: 3 nустої стодоли пусті горобиі [6, с. 143]; поміркованість, зваженість дій: 8 пустій (порожній) стодолі горобизі не тримаються [6, с. 143]; з пустої стодоли не вилетить хіба сова [6, с.143]; в пустій стодолі і миш не втримається [6, с. 143]; задоволення найменшим: коли у сіні дощчинка, то в стодолі не порожньо [2, с. 129]. Лише 2 фразеологізми містять синонімічний до стодоли компонент клуня, значення якого «Словник української мови» кодифікує таким чином: Клуня, і, ж. Будівля для зберігання снопів, сіна, полови тощо, а також для молотьби, віяння й т. ін.; стодола [8, IV, с. 192]. Ці ФО позначають злидні: багато я маю - аж три клуні хліба: в одній вітер, в другій, мак, а третя стоӥть так [6, с.143]; пішов з пустим міхом та на порожні клуні [6, с. 144].

Не набагато більше фразеологізмів фіксуємо з компонентом хлів. За «Словником української мови»: Хлів, а, ч. Будівля для свійської худоби та птиці // перен., розм. Брудне, неприбране, занедбане приміщення // рідко. Те саме, що сарай [8, XI, с. 83]. Проте діапазон значень цих ФО різноманітніший: нерозумність: а ну, синку, розкидаймо хлівецьь та нарубаємо дрівеиь [12, с. 201]; обділеність у чомусь: дав бог теля, та не дав хліва [6, с. 158]; лінощі: коли господар сидить на печі, то пусто в хліві [6, с. 128]; злодійські нахили: погане те ремесло, щзо майстра в чужий хлів занесло [2, с. 225]; багатство, достаток: на Поділлю хліб по кіллю, а ковбасами хлів городять [4, с. 164]. Як бачимо, лише одна ФО відображає позитивну реалію людського побутування (багатство), на відміну від інших - негативних, що, очевидно, пов'язано із асоціативним сприйняттям хліва як бруду (спочатку в прямому розумінні, а згодом - і в переносному).

Зі словом стайня: Стайня, i, ж. Спеціальне приміщення, будівля, де тримають коней; конюшня // у знач. збірн. Про коней, що належать комунебудь // рідко. Те саме, що хлів [8, IX, с. 637] - фіксуємо лише такі фразеологізми: господар аж тоді стайню замикає, як коней вже немає [6, с. 127] і варіант мудрий лях по шкоді: тодi стайню закриває, як вже коней в ній немає, що мають значення запізнілості, невчасності думки, діï; запозичений вираз авгієві стайні, що має значення важкко виконуваної роботи [8, IX, с. 637]. 
Зауважуємо i фразеологізми 3 компонентом хижа. «Словник української мови» подає такі значення цього слова: Хижа, i, ж, розм. 1. Те саме, що комора 1 , 2. 2. Те саме, що хата 1; невелика убога хата; халупа [8, XI, с. 52]. Фіксовані ФО мають такі значення: безгосподарність: полагодив дід [бабі] хижу: то (куди) лазили коти (кішки), [а] тепер [стали] лазять (лазить) собаки [6, с. 137] - додаткова сема «невміння»; як ніт газди в хижі, то і миші по столі скачуть [6, с. 137]; пліткарство: не замітай чужої хижі: дивися, чи твоя заметена [12, с. 186]. Негативні реалії, зображені у вказаних фразеологізмах, очевидно, мотивовані значенням хижі як убогого житла.

Навпаки, ознакою достатку й хазяйновитості була світлиця. Світлиця, і, ж. 1. Чиста, світла, парадна кімната в будинку. 2. Кімната в будинку. 3. Невелика кімната у верхній частині будинку [8, IX, с. 92]. Оскільки світлиця безпосередньо пов'язана 3 хатою, то компонент світлицяя входить до складу ФО, які мають ті ж значення, що й фразеологізми з компонентом хата, а саме: незалежнності: своя мазанка ліпиа чужої світлииі [6, с. 136] - зауважуємо тут ще одну лексему 3 лексико-семантичної групи концепту хата мазанка, якою позначають невелике вбоге житло і яка $\epsilon$ контекстуальним антонімом до слова світлиця, ця пара (мазанка - світлиця) творить антитезу - один із прийомів творення ФО; невиваженість/зваженість дії: біля гряниці не випада будувати світлиці [12, с. 190] - там будували дім (двір)-фортецю.

Окрім описаних, фіксуємо фразеологізми з компонентами кут, що мають такі значення: поваги до отчого дому (символіка хати як родового коріння): де будь, там будь, а свій кут не гудь [6, с.133]; незалежнноті: бодай ніхто не дочекав у чужім кутку вмерти [6, с.137] - збережена символіка хати як останнього притулку; бодай ніхто не діждав у чужім кутку сидіти [6, с. 137]; дупло зі значенням затишку: в своӥм дуплі сиди в mеплі [6, с.136]; господа зі значенням оберегу: піду до господи, щуоб не було шкоди [12, с. 232].

Як бачимо, українські фразеологізми 3 концептом хата (який репрезентований словами дім, двір комор і под.) утворюють досить широкий спектр значень як з позитивним, так і з негативним забарвленням. Українська мова, зокрема фразеологія, зафіксувала найважливіші, найвагоміші з погляду народу аспекти значення цього концепту, які тісно пов’язані з типовими рисами вдачі й світогляду українця, що з діда-прадіда був господарем і прагнув незалежності, злагоди та добробуту. Комплексне дослідження цього концепту дає можливість виділяти етноспрямовані парадигми, оскільки рідна хата - одне з провідних утілень української національної ментальності, що має символічне значення $і$ є тією концептуальною віссю, довкола якої тисячоліттями формувалась українська культура й український характер. 


\section{Література}

1. Сфименко О. С. Концепт «степ» в українській мові: словникова, текстова і психолінгвістична парадигма : автореф. дис. ... канд. філол. наук : 10.02.01 / О. С. Єфименко. - Х., 2005. - 19 с.

2. Міщенко Н. Слово батьків з усіх віків / Н. Міщенко, М. Міщенко. - К. : Богдана, 1998. - 1136 с.

3. Мойсеїв I. Рідна хата - категорія української духовності / І. Мойсеїв // Сучасність. - 1993. № 7. - С. 151-163.

4. Народ скаже - як зав'яже. Українські народні прислів'я, приказки, загадки. - К. : Веселка, 1973.

5. Онкович Г. В. Фразеологізми як національно-культурний компонент українознавства / Г. В. Онкович // Дивослово. - 1994. - № 9. - С. 12-16.

6. Прислів'я та приказки: Природа. Господарська діяльність людини / Упоряд. М. М. Пазяк. - К. : Наук. думка, 1989. - 480 с.

7. Савченко Л. В. Інтерпретація фразеологізмів з компонентами «земля», «небо»: етнолінгвістичний аспект / Л. В. Савченко, Т. М. Лебедєва // Лінгвостилістика : об'єкт - стиль, мета - оцінка : зб. наук. праць, присвячених 70-ти річчю від дня народження проф. С. Я. Срмоленко / Відп. ред. Академік НАН України В. Г. Скляренко. - К., 2007. - С. 439-444.

8. Словник української мови: у 11-и т. - К. : Наук. думка, 1970 - 1980. - Т. 1 - 11.

9. Телия В. Н. Русская фразеология. Семантический, прагматический и лингвокультурологический аспекты / В. Н. Телия. - М. : Школа «Языки рус. культ.», 1996. - 288 с.

10. Удовиченко Г. М. Фразеологічний словник української мови: у 2-х т. / Г. М. Удовиченко. - К. : Вища шк., 1984. - Т. 1. - 303 с. ; Т. 2. - 384 с.

11. Ужченко Д. В. Символ - концепт - компонент фразеологізму / Д. В. Ужченко // Вісник Харків. нац. ун-ту : Серія : Філологія. - № 491. - Х. : ХНУ, 2000. - С. 47-50.

12. Українські приказки, прислів'я і таке инше / Зб. О. Марковича и других / Упоряд. М. Номис. СПб., 1864. - VII, 804, XVII с.

13. Фразеологічний словник української мови / Уклад. Білоноженко В. М. та ін. - Кн. 1-2. - К. : Наук. думка, 1993.

14. Франко І. Вибрані статті про народну творчість : [текст] / І. Франко; упоряд. канд. філолог. наук О. І. Дей. - К. : АН УРСР, 1955. - 289 с. 